\title{
Increase in Enzyme Activities in Embryonic Axes of Soybean Seeds during Germination
}

\author{
Shin-ichi OKuda, Jun Kaneko, Toshiya Ogawa, \\ Takuya YamaguchI, ${ }^{*}$ Kazuo IzaKi \\ and Hajime TAKAHASHI \\ Department of Agricultural Chemistry, Faculty of Agriculture, \\ Tohoku University, Sendai 980, Japan \\ *Product Research Laboratory, Oji Paper Co., Ltd., \\ Tokyo 135, Japan
}

Received June 23, 1986

\begin{abstract}
The changes in enzyme activities in embryonic axes of soybean seeds during germination were investigated. After $48 \mathrm{hr}$ of germination, the activities of 6-phosphogluconate, glucose-6-phosphate, and L-isocitrate dehydrogenases were $2 \sim 4$ times as high those of embryonic axes from dry seeds. The activities of L-glutamate and meso-D-diaminopimelate dehydrogenases and of L-isocitritase, however, were still low. The activities of L-malate dehydrogenase and acid phosphatase increased strikingly after germination, and the activities of the germinated axes were about 80 (at $48 \mathrm{hr}$ ) and 27 (at $40 \mathrm{hr}$ ) times, respectively, those of embryonic axes from dry seeds. The elevated activity of acid phosphatase was due to de novo synthesis of enzyme protein in the embryonic axes, not to activation of the enzyme protein, or to transfer of the enzyme protein from germinating cotyledons. Acid phosphatase activity in embryonic axes increased in a very early stage of protein synthesis in the axes. The pronounced increase in L-malate dehydrogenase activity was mainly due to activation of the enzyme protein by imbibition, not to de novo synthesis of enzyme protein, or to transfer of the. enzyme protein from germinating cotyledons.
\end{abstract}

The first process of germination is the uptake of water by seeds during imbibition. ${ }^{1)}$ A number of physical and biochemical changes in the seed result in its germination and subsequent elongation of the embryonic axis. Details of the mechanism of germination, including the early stage of elongation of the embryonic axis, are not known.

Nothing is known about the control of gene expression involved in germination. To study the structure of the genes that are actively transcribed in germination, enzymes that are actively synthesized in this process must first be identified. Here, we describe the pronounced increase in the activities of acid phosphatase and L-malate dehydrogenase in axes of soybean during germination of the seed. The increased activity of acid phosphatase was due to de novo synthesis of enzyme protein, and the increased activity of L- malate dehydrogenase was mainly due to activation of the enzyme protein by imbibition.

\section{MATERIALS AND METHODS}

Seeds and germination conditions. Soybean seeds (Glycine $\max$ L.) were purchased from Snow Brand Seed Co., Ltd., Sapporo. The seeds were soaked in a solution of $2 \%(\mathrm{w} / \mathrm{v})$ calcium hypochlorite for $15 \mathrm{~min}$, washed throughly with deionized water, and allowed to imbibe water at $25^{\circ} \mathrm{C}$. After $1 \mathrm{hr}$ of imbibition, seeds were germinated either on a $0.7 \%$ agar plate or in moist vermiculite in the dark at $25^{\circ} \mathrm{C}$. The embryonic axes were harvested at various stages of germination and used for the experiments. The time of the addition of water with or without inhibitor(s) to the dry seeds was taken as the zero time of germination. To examine the enzyme activities of axes after 3,24 , and $47 \mathrm{hr}$ of germination, at which time the effect of cotyledons could be ignored, embryonic axes were detached from dry seeds, allowed to imbibe water, and incubated on $0.7 \%$ agar plates as described above.

When the effects of cycloheximide or chloramphenicol 
on the increase in the enzyme activities were examined, imbibition and germination were carried out in the presence of these inhibitors at the concentrations described in the text.

Labeling experiments. Dry seeds were soaked in a solution containing $0.2 \mu \mathrm{Ci} \mathrm{L}-\left(\mathrm{U}-{ }^{14} \mathrm{C}\right)$ amino acid mixture $(50 \mathrm{mCi} / \mathrm{mAtom}$, Radiochemical Center, Amersham, U.K.), $2 \mu \mathrm{Ci}\left[5-{ }^{3} \mathrm{H}\right]$ uridine $(29 \mathrm{Ci} / \mathrm{mmol}$, Radiochemical Center), and $0.3 \mathrm{mg}$ of chloramphenicol in a total volume of $10 \mathrm{ml}$. After $1 \mathrm{hr}$ of soaking in the solution, seeds were incubated on $0.7 \%$ agar plates containing these three chemicals at the same concentrations as above, and harvested at the different periods of incubation time described in the text. Fifteen axes were harvested and homogenized in $8 \mathrm{ml}$ of cold extraction buffer consisting of $20 \mathrm{~mm}$ Tris$\mathrm{HCl}$ (pH 8.0), $10 \mathrm{~mm} \mathrm{MgCl} 2,20 \mathrm{~mm} \mathrm{KCl}, 5 \mathrm{~mm}$ 2-mercaptoethanol, and $0.5 \%(\mathrm{w} / \mathrm{v})$ sodium deoxycholate as described by Minamikawa et al. ${ }^{2)}$ After centrifugation of the homogenate at $15,000 \times g$ for $30 \mathrm{~min}$, cold trichloroacetic acid (TCA) was added to a final concentration of $5 \%$. The precipitate was collected on a glass fiber disk (Toyo GC75, Toyo Roshi Co., Ltd., Tokyo), and washed with $5 \%$ TCA and $80 \%$ ethanol. The radioactivity of $80 \%$ ethanolinsoluble materials was counted on an Aloka 900 liquid scintillation spectrometer (Aloka Co., Ltd., Tokyo) with toluene-Nonione scintillation fluid described by Kawakami and Shimura, ${ }^{3}$ except that POPOP was omitted.

Preparation of cell extract and assay of enzyme activities. The embryonic axes obtained were ground at $4{ }^{\circ} \mathrm{C}$ with quarts sand (half weight of axes, w/w) and an extraction buffer ( $3 \sim 8$ times as much as axes, $\mathrm{v} / \mathrm{w})$ with a mortar and pestle. The extraction buffer was composed of $0.05 \mathrm{M}$ Tris$\mathrm{HCl}(\mathrm{pH} 7.7), 5$ mм 2-mercaptoethảnol, 5 mм EDTA, and $0.5 \mathrm{~mm}$ phenylmethylsulfonium fluoride. The resultant homogenate was squeezed through a nylon cloth and centrifuged at $16,000 \times g$ for $20 \mathrm{~min}$. The supernatant fraction (cell extract) was used for assays of various enzymes.

Activities of glucose-6-phosphate (G6P) and 6-phosphogluconate (6PG) dehydrogenases (EC 1.1.1.49 and EC 1.1.1.44) were assayed by the procedure of Muto and Uritani. ${ }^{4)}$ The reaction mixture for the $6 \mathrm{PG}$ dehydrogenase assay contained $0.05 \mathrm{~mm}$ Tris- $\mathrm{HCl}(\mathrm{pH} 7.7), 1 \mathrm{~mm}$ $\mathrm{NADP}^{+}$, cell extract, and $1.7 \mathrm{~mm} 6 \mathrm{PG}$ as the substrate in a total volume of $3.0 \mathrm{ml}$. For the G6P dehydrogenase assay, $1.7 \mathrm{~mm}$ G6P was also added to the above reaction mixture as a substrate. The reaction was started by the addition of either 6PG or both 6PG and G6P. The activity was measured by the initial rate of reduction of $\mathrm{NADP}^{+}$at $25^{\circ} \mathrm{C}$. The increase in absorbance at $340 \mathrm{~nm}$ was recorded by a Hitachi spectrophotometer (type 124). The amount of $\mathrm{NADP}^{+}$reduced was calculated with the molar extinction coefficient of NADPH of $E_{340 \mathrm{~nm}}=6.27 \mathrm{~cm}^{2} / \mu \mathrm{mol}$, which was found with the Hitachi spectrophotometer. The difference in the $\mathrm{NADP}^{+}$reduction rate between the assays in which 6PG or both 6PG and G6P were included as substrates was used to calculate the G6P dehydrogenase activity.

L-Isocitrate dehydrogenase (EC 1.1.1.42) activity was measured by the methods of Nagamachi and Honda ${ }^{5)}$ with some modifications. The reaction mixture contained $0.041 \mathrm{M}$ Tris- $\mathrm{HCl}$ (pH 8.0), $3.3 \mu \mathrm{M} \mathrm{MnCl}_{2}, 0.067 \mathrm{~mm}$ $\mathrm{NADP}^{+}$, cell extract, and $0.85 \mathrm{~mm}$ DL-isocitrate as the substrate in a total volume of $3.0 \mathrm{ml}$. The enzyme activity was measured at $25^{\circ} \mathrm{C}$ as for the assay of $6 \mathrm{PG}$ dehydrogenase.

L-Malate dehydrogenase (EC 1.1.1.37) activity was assayed by the procedure of Nawa and Asahi ${ }^{6)}$ with some modifications. The cell extract was dialyzed against $0.05 \mathrm{M}$ potassium phosphate buffer $(\mathrm{pH} 7.5)$ before use. The reaction mixture contained $0.05 \mathrm{M}$ potassium phosphate buffer ( $\mathrm{pH} 7.5$ ), $0.33 \mathrm{~mm} \mathrm{NADH}, 0.2 \%$ Triton X-100, $0.4 \mathrm{~mm}$ oxalacetate, and dialyzed cell extract in a total volume of $3.0 \mathrm{ml}$. The enzyme activity was measured by the initial rate of $\mathrm{NADH}$ oxidation at $25^{\circ} \mathrm{C}$. The amount of NADH oxidized was also calculated from the decrease in absorbance at $340 \mathrm{~nm}$.

The activity of acid phosphatase (EC 3.1.3.2) was assayed in $3.0 \mathrm{ml}$ of a reaction mixture containing $0.2 \mathrm{M}$ sodium acetate ( $\mathrm{pH} 5.8), 1 \mathrm{~mm}$ p-nitrophenylphosphate, and cell extract as described by Uehara et al. ${ }^{7)}$ Cell extract that was prepared in a solution containing $0.05 \mathrm{M}$ Tris$\mathrm{HCl}(\mathrm{pH} 7.7)$ was diluted $1: 100$ with $0.06 \mathrm{M}$ acetate buffer $(\mathrm{pH}$ 5.8) and used for the enzyme assay. The reaction was started by the addition of the substrate at $30^{\circ} \mathrm{C}$. After $10 \mathrm{~min}$ of incubation, the reaction was stopped by the addition of $1 \mathrm{ml}$ of $0.4 \mathrm{~N} \mathrm{NaOH}$. The $p$-nitrophenol formed was assayed by measurement of absorbance at $410 \mathrm{~nm}$.

One unit of the enzyme activities assayed was defined as $1 \mu \mathrm{mol}$ of $\mathrm{NADP}^{+}$reduced, $\mathrm{NADH}$ oxidized, or $p$ nitrophenol formed per minute per embryonic axis.

\section{RESULTS}

\section{Changes in fresh and dry weights and synthesis of substances of high molecular weight during germination}

Both fresh and dry weights of the axes increased after about $24 \mathrm{hr}$ of germination (Fig. 1). Marked incorporation of both ${ }^{14} \mathrm{C}$ and ${ }^{3} \mathrm{H}$ radioactivity into the acid-insoluble fraction was also observed after $24 \mathrm{hr}$ when soybean seeds were germinated in the presence of both a ${ }^{14} \mathrm{C}$-amino acid mixture and $\left[{ }^{3} \mathrm{H}\right]$ uridine (Fig. 2). These results indicated that both protein and RNA synthesis started about $24 \mathrm{hr}$ after imbibition started. 


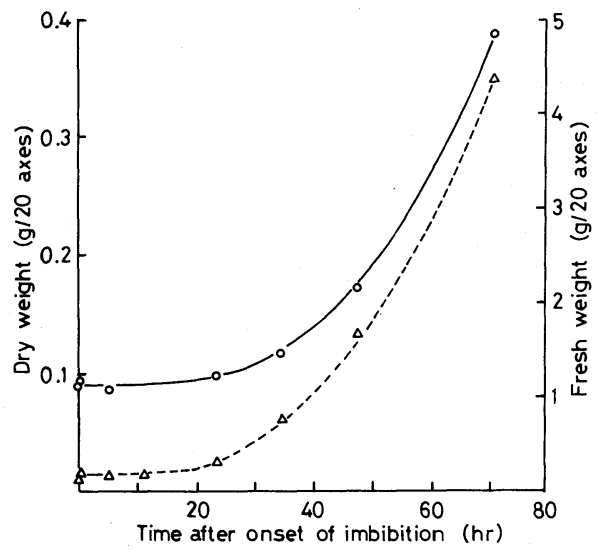

FIG. 1. Changes in Fresh and Dry Weights of Embryonic Axes during Germination of Seeds.

$-\bigcirc-$, dry weight; --- $\triangle---$, fresh weight.

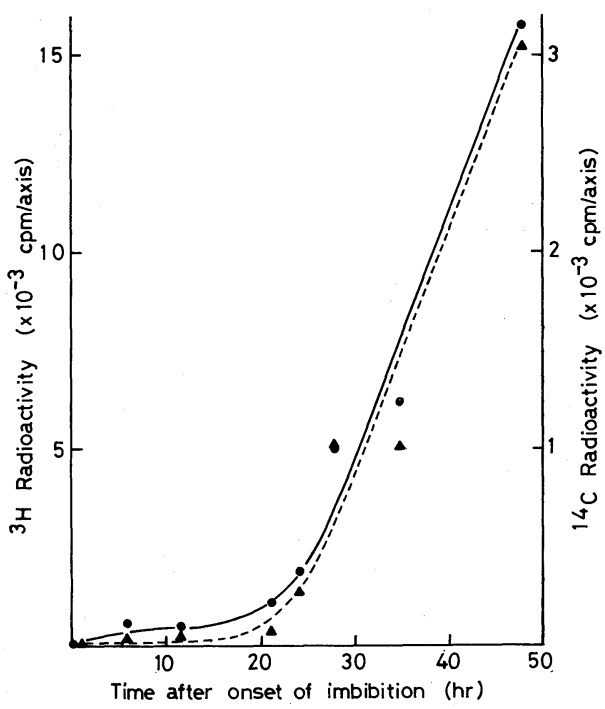

FIG. 2. Incorporation of $\mathrm{L}-\left(\mathrm{U}-{ }^{14} \mathrm{C}\right)$-Amino Acid Mixture and $\left[5-{ }^{3} \mathrm{H}\right]$ Uridine into TCA-insoluble and $80 \%$ Ethanol-insoluble Fractions of Embryonic Axes of Germinating Seeds.

- - ${ }^{14} \mathrm{C} ;---\mathbf{\Delta}---,{ }^{3} \mathrm{H}$.

Changes in enzyme activities in embryonic axes during germination of seeds

The activities of L-malate dehydrogenase and acid phosphatase increased greatly by $24 \mathrm{hr}$ after imbibition started, and their activities in the germinated axes were about 80 (at $48 \mathrm{hr}$ ) and 27 (at $40 \mathrm{hr}$ ) times those of embryonic axes from dry seeds (dry axes), respectively (Fig. 3).

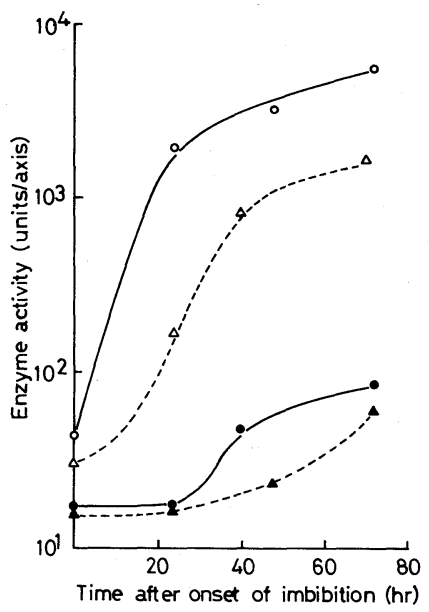

FIG. 3. Increase in Enzyme Activities of Embryonic Axes of Germinating Seeds.

- $\bigcirc-$, L-malate dehydrogenase; --- $\triangle---$, acid phosphatase; - -, 6 PG dehydrogenase; --- $\mathbf{\Delta - - - , ~ L - i s o c i t r a t e ~}$ dehydrogenase.

The activities of 6PG and L-isocitrate dehydrogenases at $24 \mathrm{hr}$ were about the same as those in dry axes. After $48 \mathrm{hr}$ of germination, these enzyme activities were $2 \sim 4$ times those from dry axes. G6P dehydrogenase activity of axes after $40 \mathrm{hr}$ of germination was 3 times that from dry axes (data not shown). The activities of L-isocitritase (EC 4.1.3.6), Lglutamate dehydrogenase (EC 1.4.1.2), and meso- $\alpha, \varepsilon$-diaminopimelate $\mathrm{D}$-dehydrogenase (EC class 1.4.1) were very low after $48 \mathrm{hr}$ of germination (data not shown).

To decide whether the increased activities of L-malate dehydrogenase and acid phosphatase were due to de novo synthesis of enzyme proteins, we examined the effects of cycloheximide and chloramphenicol on the enzyme activities. The increase in L-malate dehydrogenase activity was not prevented by either inhibitor. The increases in 6PG dehydrogenase and acid phosphatase activities were inhibited by cycloheximide, but not by chloramphenicol (Table I).

In the next experiments, embryonic axes were detached from dry seeds to exclude the possibility of transfer of enzyme proteins from cotyledons. To reduce the time required for harvesting axes from germinating seeds, de- 
Table I. EfFects of CycloheXimide or Chloramphenicol on the InCREASE in Enzyme Activities of Embryonic Axes Harvested from Seeds Germinated for $24 \mathrm{hr}$ in the Presence OF ONE INHIBITOR

\begin{tabular}{|c|c|c|c|c|}
\hline \multirow{2}{*}{$\begin{array}{l}\text { Inhibitor } \\
\text { added }\end{array}$} & \multirow{2}{*}{$\begin{array}{c}\text { Fresh weight } \\
\text { of axis } \\
(\mathrm{mg})\end{array}$} & \multicolumn{3}{|c|}{ Enzyme activity (units/axis) } \\
\hline & & $\begin{array}{c}\text { 6-Phosphogluconate } \\
\text { dehydrogenase }\end{array}$ & $\begin{array}{c}\text { Acid } \\
\text { phosphatase }\end{array}$ & $\begin{array}{c}\text { L-Malate } \\
\text { dehydrogenase }\end{array}$ \\
\hline None & 23 & 24 & 167 & $3.5 \times 10^{3}$ \\
\hline $\begin{array}{c}\text { Cycloheximide } \\
16.7 \mu \mathrm{M} \\
50.0 \mu \mathrm{M}\end{array}$ & $\begin{array}{r}11 \\
9\end{array}$ & $\begin{array}{l}13 \\
11\end{array}$ & $\begin{array}{l}36 \\
35\end{array}$ & $\begin{array}{l}3.7 \times 10^{3} \\
3.7 \times 10^{3}\end{array}$ \\
\hline $\begin{array}{c}\text { Chloramphenic } \\
2.0 \mathrm{~mm} \\
5.0 \mathrm{mM}\end{array}$ & $\begin{array}{l}18 \\
22\end{array}$ & $\begin{array}{l}31 \\
34\end{array}$ & $\begin{array}{l}155 \\
169\end{array}$ & $\begin{array}{l}3.4 \times 10^{3} \\
2.8 \times 10^{3}\end{array}$ \\
\hline
\end{tabular}

TABle II. EFFects of $3 \mathrm{hr}$ of Germination ON Enzyme Activities of Detached Axes in the PRESENCE OF Both CyCloheXimide $(16.7 \mu \mathrm{M})$ AND Chloramphenicol $(5.0 \mathrm{~mm})$

\begin{tabular}{lccc}
\hline \multirow{2}{*}{ Enzyme } & \multicolumn{2}{c}{ Germination } & \\
\cline { 2 - 3 } & $\begin{array}{c}\text { Before } \\
\text { (B) }\end{array}$ & $\begin{array}{c}\text { After } \\
\text { A) }\end{array}$ & \\
\hline Acid phosphatase & 30 & 52 & 1.7 \\
L-Malate dehydrogenase & 43 & 6000 & 140 \\
\hline
\end{tabular}

Enzyme activities are expressed as units/axis.

tached axes were allowed to germinate for a short time. The detached axes were germinated for $2 \mathrm{hr}$ after imbibition for $1 \mathrm{hr}$ in the presence of both of these two inhibitors. The activities of L-malate dehydrogenase and acid phosphatase were about 140 and 1.7 times those from dry axes, respectively (Table II). Results shown in Tables I and II indicated that the increased activity of L-malate dehydrogenase in germinating axes was mainly due to the activation of the enzyme by imbibition, not to de novo synthesis of the enzyme proteins, nor to transfer of enzyme protein from the cotyledons.

When detached axes were incubated on agar plates for $47 \mathrm{hr}$ without the addition of these two inhibitors, the axes elongated from $0.4 \mathrm{~cm}$ to about $1.6 \mathrm{~cm}$, while axes elongated to about $4.1 \mathrm{~cm}$ if seeds were allowed to germinate for $47 \mathrm{hr}$ (data not shown). Although elongation
Table III. Acid Phosphatase Activity from Axes Harvested from Germinated SeEds (AtTACHED AXES) AND InCUbATED as DeTaChed Axes

\begin{tabular}{|c|c|c|c|}
\hline \multirow{2}{*}{ Axes } & \multicolumn{3}{|c|}{$\begin{array}{l}\text { Time after onset of } \\
\text { imbibition (hr) }\end{array}$} \\
\hline & 0 & 24 & 47 \\
\hline Attached & 30 & 167 & 1389 \\
\hline Detached & 30 & 250 & 570 \\
\hline
\end{tabular}

Enzyme activity is expressed as units/axis.

of detached axes was less than that of axes from germinating seeds, the acid phosphatase activity from detached axes was about 8 and 19 times that from dry axes when the detached axes were incubated on agar plates for 24 or $47 \mathrm{hr}$, respectively (Table III). The acid phosphatase activity of embryonic axes harvested from seeds germinated for 24 and $47 \mathrm{hr}$ was about 5 and 46 times that of dry axes, respectively (Table III). The results shown in Tables I, II and III indicate that the increase in acid phosphatase activity from germinating axes was due to de novo synthesis of the enzyme protein, not to transfer of enzyme protein from the cotyledons, or activation of enzyme by imbibition.

\section{DISCUSSION}

After plant seeds imbibe water, the meta- 
bolic activities of the seeds increase greatly, resulting in germination. The metabolic changes in the early stages of germination are the result of activities of various enzymes, which are either present in the dry seed or very rapidly activated as the seeds imbibe water. $^{8)}$ In addition, some enzyme proteins are newly synthesized after imbibition starts.

A number of studies of changes in enzyme activities during germination have been reported. The profile of change in enzyme activities depends on the species of plant..$^{9 \sim 11}$ )

Little information is available about the regulation of gene expression in germinating seed. To clone genes expressed in germination, it would be necessary to isolate enzymes that are absent in dry seed and are actively synthesized in germinating seed. Of the enzymes from soybean axes that we tested, acid phosphatase activity increased most during germination. In the experiments with detached axes, the elevated activity of acid phosphatase was not the result of transfer of the enzyme molecules from cotyledons. De novo synthesis of this enzyme occurred before most of the protein synthesis in the embryonic axes, which suggested that this enzyme was particularly important in germination. One possible role of acid phosphatase in germinating embryonic axes is to cause turnover of the phosphate esters in the seed. ${ }^{12,13)}$ L-Malate dehydrogenase activity also increased greatly at an early stage of germination, but the increase was not inhibited by cycloheximide or chloramphenicol. These results indicated that the increase in L-malate dehydrogenase activity was due to the activation of the enzyme protein by imbibition, not to synthesis of the enzyme protein. Therefore, acid phosphatase is a suitable enzyme for the study of gene expression during germination of soybean seeds.

L-Malate dehydrogenase was activated within $3 \mathrm{hr}$ of the start of imbibition even when both cycloheximide and chloramphenicol were present. This is consistent with observations that cytochrome oxidase (EC 1.9.3.1) and Lmalate dehydrogenase level rise. ${ }^{14)}$ Preformed proteins, both structural and enzymic, seem to be transferred into preformed immature mitochondria following imbibition, resulting in active, efficient mitochondria with a complete membrane and respiratory system. ${ }^{15}$, The mechanism of activation of this enzyme is unknown.

Acknowledgments. The authors thank Dr. T. Minamikawa of Tokyo Metropolitan University for his helpful advice. We are also grateful to Miss A. Sato of our faculty for operation of the liquid scintillation spectrometer. This work was supported in part by a grant from The Research Council, Ministry of Agriculture, Forestry and Fisheries, Japan.

\section{REFERENCES}

1) A. M. Mayer and A. Poljakoff-Mayber, "The Germination of Seeds," Pergamon Press Ltd., Oxford, 1982, p. 26.

2) T. Minamikawa, Y. Suzuki and T. Koshiba, Plant and Cell Physiol., 24, 1361 (1983).

3) M. Kawakami and K. Shimura, Radioisotopes, 23, 15 (1974).

4) S. Muto and.I. Uritani, Plant and Cell Physiol., 11, 767 (1970).

5) K. Nagamachi and K. Honda, Nippon Nôgeikagaku Kaishi, 41, 99 (1967).

6) Y. Nawa and T. Asahi, Plant Physiol., 48, 671 (1971).

7) K. Uehara, S. Fujimoto and T. Taniguchi, $J$. Biochem., 75, 627 (1974).

8) A. M. Mayer and A. Poljakoff-Mayber, "The Germination of Seeds," Pergamon Press Ltd., Oxford, 1982, p. 94.

9) J. D. Bewley and M. Black, "Physiology and Biochemistry of Seeds in Relation to Germination," Vol. I, Springer-Verlag, Berlin, 1983, pp. 132 241.

10) J. D. Bewley and M. Black, "Seeds: Physiology of Development and Germination," Plenum Press, New York, 1985, pp. 135 171, 253 301.

11) A. M. Mayer and A. Poljakoff-Mayber, "The Germination of Seeds," Pergamon Press Ltd., Oxford, 1982, pp. $85 \sim 138$.

12) J. D. Bewley and M. Black, "Seeds: Physiology of Development and Germination," Plenum Press, New York, 1985, pp. 298 300.

13) A. M. Mayer and A. Poljakoff-Mayber, "The Germination of Seeds," Pergamon Press Ltd., Oxford, 1982, p. 113

14) Y. Nawa and T. Asahi, Plant Physiol., 51, 833 (1973).

15) J. D. Bewley and M. Black, "Physiology and Biochemistry of Seeds in Relation to Germination," Vol. I, Springer-Verlag, Berlin, 1983, pp. 144 146. 